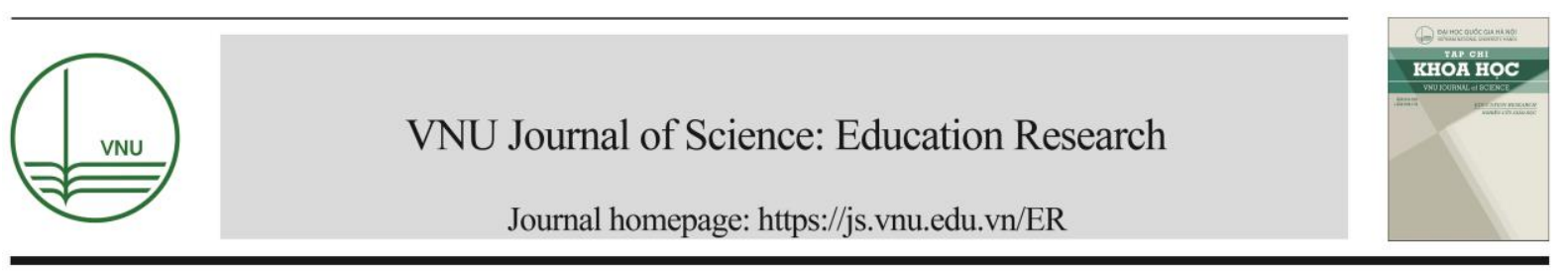

Review Article

\title{
Implementation of Local Wisdom Values of Piil Pesenggiri as Character Education in Indonesian History Learning
}

\author{
Regiano Setyo Priamantono*, Warto, Akhmad Arif Musaddad \\ Graduate Student, Department of History Education, \\ Sebelas Maret University, Surakarta, Indonesia
}

Received 04 February 2019

Revised 11 March 2020; Accepted 09 April 2020

\begin{abstract}
The objectives of this study are: i) to find out the implementation of character education; ii) to find out the implementation of Piil Pesenggiri local wisdom values as character education in Indonesian history learning; and iii) to find out the obstacles in the implementation of Piil Pesenggiri local wisdom values as character education in Indonesian history learning. The method used in this research is descriptive qualitative research method with a case study approach in State Senior High School 2 Kalianda. The results showed that: i) the implementation of character education in State Senior High School 2 Kalianda was generally applied to all subjects, including Indonesian history subjects; ii) the implementation of Piil Pesenggiri local wisdom values as character education in the process of Indonesian history learning was carried out by compiling a syllabus and lesson plan (RPP) by incorporating into Indonesian historical material about the Lampung people's resistance strategy toward European colonization consisting of the stages of planning, implementation, and evaluation; and iii) the constraints experienced by teachers in implementing Piil Pesenggiri local wisdom values as character education in the process of learning history includes the lack of learning resources and the negative influence of the globalization era.
\end{abstract}

Keywords: Piil Pesenggiri, Character Education, Indonesian History Learning.

\section{Introduction}

Education is currently in the spotlight by various groups, because the world of education

\footnotetext{
${ }^{*}$ Corresponding author.

E-mail address: regiano.unila@gmail.com

https://doi.org/10.25073/2588-1159/vnuer.4366
}

which main function is to form intelligent and noble individual is considered to be less serious in educating the character of the younger generation. Many problems involving the character of the younger generation such as drug abuse among students, promiscuity, crime, acts of violence such as persecution, fighting, bring into conflict, etc. are indications that 
something is wrong in the world of education. In addition, many young people who fail to be commendable, the declining moral behavior of the younger generation as described above seems to invite concern from various groups. Therefore, the government decision through the national education minister to launch character education is a step that is considered very appropriate. One of them is by applying character education in learning in high school (Billig, 2008: 21; Twemlow, 2001: 808; Weissbourd, 2003: 6) [1-3].

School is an institution that has a strategic role in educating and preparing quality of human resources in holding the previous generation relay (Johnson, 2002: 65; Simpson, 2005: 182) $[4,5]$. The existence of school as a system of social life, places school institutions as part of the social system. As part of a social system and institution, schools must be sensitive and responsive to the expectations and demands of the surrounding community. Schools are expected to carry out their functions by educating the nation life optimally and securing themselves from negative environmental influences (Benninga, 2003: 19; Damon, 2002: 9) [6, 7]. Therefore, this study seeks to present the role of schools in creating an atmosphere of character education learning to students.

One of the subjects that has a character education content is History of Indonesia (Althof, 2006; Aman, 2011: 57; Wineburg, 2001: 6; 495) [8-10]. Indonesian historical subject is a lesson that instill knowledge, attitudes and process values regarding the change and development of Indonesian society from the past until now. The values contained in the learning of Indonesian history are scientific values, informative values, ethical values and national values (Kochar, 2008: 54) [11]. So it is clear that Indonesian history lesson not only support student knowledge but contain other aspects that students need in life.

The character values expected by the government are 18 values, including religious values, tolerance, honesty, discipline, hard work, creative, independent, curiosity, democratic, patriotism, nationality, respect for achievement, friendship, love for peace, likes to read, care about the environment, social, and responsibility (Setiawan, 2018: 41) [12]. These character values are apparently embodied in the philosophy of life possessed by the Lampung people namely Fiil Pesenggiri (Amaliah, 2018: 179; Mulyana, 2004: 9; Sinaga, 2014) [13-15]. Fiil Pesenggiri is the nature, behavior and outlook on life possessed by Lampung people (Rahyono, 2009: 11; Utami, 2018: 61) [16, 17].

Instilling the values of Fiil Pesenggiri as character education does not have to be centered on Indonesian historical material but can also be through local historical material (Priyadi, 2012; Tery, 2018) [18, 19], through Indonesian History lessons based on local history is the basis for the development of personal, cultural identity, and social students (Fitzsimons, 2015; Hasudungan, 2019: 228) $[20,21]$. A special advantage possessed by local history teaching is the ability to bring students to more real situations in their environment, in other words as if they are able to break through the boundary between the school world and the real world around the school (Romanowski, 2015; Yunus, 2014) [22, 23].

Based on previous research conducted by Ariyani (2014: 82) [24] states that there are character words in the explanation of the philosophy of life owned by Lampung people, namely i) Piil Pesenggiri, ii) Bejuluk Beadek, iii) Nemui Nyimah, iv) Nengah Nyappur, v) Sakai Sambayan. This is in accordance with the research conducted by Sadikin Ali (2018) [25], showing that: i) the values of Piil Pesenggiri are contained in syaer including the values of sakai sambaian, nemui nyimah, nengah nyappur, and bejuluk beadek, and ii) Piil Pesenggiri values that are relevant to the value of character education and are needed in the process of fostering one's personality are togetherness, mutual cooperation, solidarity, sincerity, respect, tolerance, community, empathy, humility, discipline and responsibility.

Based on the background that has been explained, the researcher is interested in conducting research with the title 
"Implementation of Piil Pesenggiri Local Wisdom Value as Character Education in Indonesian History Learning at State Senior High School 2 Kalianda, South Lampung". The purpose of this study was to determine the implementation of character education in State Senior High School 2 Kalianda. To find out the implementation of the Piil Pesenggiri values as character education in the learning process of Indonesian history in class XI students at State Senior High School 2 Kalianda, and to find out the constraints experienced by the teacher when implementing the Piil Pesenggiri values as character education in the learning process of Indonesian History in students class XI at State Senior High School 2 Kalianda.

\section{Methodology}

This research uses descriptive qualitative research methods with a case study approach. Case studies include studies of cases in real life, in the current context (Creswell, 2018) [26]. Data collection techniques consisted of participant observation, in-depth interviews and documentation (Sugiyono, 2015) [27]. Determination of informants using purposive sampling techniques then developed again with the snowball sampling technique. With a purposive sampling technique, finally the sample that became the main informant was determined: Ms. Nana as history teacher class XI IPS 1 and 2. Then the main informant suggested another informant, namely: Ms. Yeni as history teacher class XI IPS 3 and 4 as well as from students of class XI IPS totaling 4 students. Data analysis techniques using the model of Miles and Huberman (2017) [28] consisting of data reduction, data presentation, and verification/ conclusion. The validity of the data is carried out using triangulation techniques, which are techniques used in qualitative research to check and build validity by analyzing data from various instruments, consisting of triangulation of techniques and sources (Patton, 2009; Sukmadinata, 2005) [29, 30].

\section{Results and Discussion}

\subsection{The Implementation of Character Education in State Senior High School 2 Kalianda}

The implementation of character education is inseparable from the functions and objectives of national education, that is, national education functions to develop capabilities and shape the character and civilization of a dignified nation in order to educate the nation's life, it aims to develop students to become people of faith and piety, noble character and good personality as an Indonesian citizen.

The implementation of character education in State Senior High School 2 Kalianda is carried out outside the classroom and inside the classroom (Agboola, 2012: 163) [31] when the class time is taking place, this is intended so that students better understand the character values and attitudes that are formed when implementing the character education, so students will behave well in the school environment and in the community later (Siswati, 2018: 6) [32]. The results of a research interview with Teacher Nana, "The implementation of character education that takes place outside the classroom when viewed from the results of the researchers interview with informants, the implementation of character education such as the application of the $5 \mathrm{~S}$ (senyum, sapa, salam, sopan, dan santun or smile, greeting, salaam, polite, and respectful), besides shaking hands with the teacher, pushing the motorcycle when entering State Senior High School 2 Kalianda and an orderly motorcycle parking".

The implementation of character education at State Senior High School 2 Kalianda is not only done outside the classroom but also carried out in the classroom. The process of implementing character education is manifested in a variety of school programs in learning. The implementation of character education is carried out by internalizing the learning material, if it is theoretically reviewed according to the strategy of implementing character education, because it integrates 
learning. This integration has a positive impact because indirectly students will learn character (Sutarmi, 2016: 14) [33].

The character education of State Senior High School 2 Kalianda is carried out integrated into all subjects, especially the subjects of Indonesian history and PPKn. The intended integration includes the loading of values into the substance of Indonesian history and PPKn subjects. Learning activities facilitate the practice of values in activities inside and outside the classroom for each subject. The most important innovation of character education and direct contact with daily learning activities is the integration of character education in the learning process.

Integrating characters in the learning process of Indonesian history and PPKn in schools is one of the most widely applied models. This model is applied by the paradigm that the teachers of Indonesian history and PPKn are character educators. Indonesian history lessons and PPKn have a mission to form attitudes of noble character for students, so that students have an insight into nationalism, love of the motherland, and the spirit of nationalism towards Indonesia. Integration of character education in State Senior High School 2 Kalianda is through the subjects of Indonesian history and PPKn. The teachers of Indonesian history and PPKn are expected to be able to bring students to have a high spirit of nationalism and patriotism, and can be an example of schools in Kalianda, South Lampung.

\subsection{The Implementation of Local Wisdom} Values of Piil Pesenggiri as Character Education in Learning Indonesian History at State Senior High School 2 Kalianda

The Implementation of Piil Pesenggiri local wisdom values as Character Education in Indonesian History Learning includes three stages of activity, namely: the planning stage, the implementation stage, and the evaluation stage (Creswell, 2015) [34].

3.2.1. Planning Statge
At the planning stage (Majid, 2013) [35] the teacher makes a learning kit that includes a syllabus and lesson plan (RPP). The learning implementation plan is made by the teacher in the hope that the learning implementation can run systematically and can achieve the learning objectives that have been prepared (Lestari, Saraswati, \& Muntholib, 2018; Warsono \& Hariyanto, 2017) [36, 37]. According to Hamalik (2011: 135) [38] the function of the learning planning stage is as follows: i) gives the teacher an understanding of the learning carried out to achieve certain goals; ii) helps the teacher in clarifying thoughts about the values of learning and the procedures required; iii) assisting teachers in clarifying thoughts about the contribution of learning to educational goals; iv) helping teachers recognize students' needs, and motivating them; v) reducing the risk of trial and error in the learning process; and vi) helping teachers always provide up to date material to students.

The results of a research interview with Teacher Yeni, she stated: "At the planning stage, the Indonesian history teacher at State Senior High School 2 Kalianda, has composed a syllabus and lesson plan that included the values of the Piil Pesenggiri which included character education. The syllabus has not explicitly been associated with character values and adjusted to basic competition or $\mathrm{KD}$ and Indonesian historical material". So that the effort to implement the Piil Pesenggiri Local Wisdom values as Character Education in Indonesian History Learning can be carried out well, then a teacher must better understand the concept of the Piil Pesenggiri Local Wisdom values as Character Education.

Teachers will find it easier to prepare Syllabus and lesson plans in the learning process such as loading material and assessments (Najib, 2013: 15) [39]. The results of a research interview with Teacher Nana, she stated: "At this planning stage, the teacher prepares a syllabus and lesson plan (RPP) by incorporating local historical material (Chairiyah, 2017: 208) [40] Lampung people's resistance to Dutch colonialism which contains 
Piil Pesenggiri values into Indonesian history material contained in KD 3.2 analyzing Indonesian resistance strategy against European colonization (Portuguese, Spanish, Dutch, English) until the 20th century".

The research plan takes place in four classes, namely: class XI IPS 1, XI IPS 2, XI IPS 3, and XI IPS 4 on 21 and 23 January 2020. Preparation of learning in class is an effort to implement the values of Piil Pesenggiri according to history teachers according with proper procedures. The teacher prepares a special record of local history learning material that contains values of Piil Pesenggiri such as Lampung people's resistance against Dutch colonialism because the material has not been included in the discussion material contained in the textbook (Harrison, 2001) [41] or the Indonesian history worksheet, the material still new for teachers and students. But the teacher has no difficulty in delivering the material. The material is very related to the subject matter that already exists, it's just that the scope of the subject is in the local history of the school environment (Kagan, 2001) [42].

3.2.2. Implementation Statge

At the implementation stage of Piil Pesenggiri values in learning history (Wiriaatmaja, 2002) [43] when they were about to start learning in class, the teacher gave apperception in the form of greetings and presence for students who did not enter the classroom. It happened in all classes that were the object of research in class XI IPS 1, XI IPS 2, XI IPS 3 and XI IPS 4, then the teacher explained the aims and objectives of learning namely analyzes forms of resistance the people of Lampung against the Dutch colonialism which contains Piil Pesenggiri values. When delivering the material, the teacher starts by giving questions to students about what forms of resistance the people of Lampung against the Dutch colonialism and give one example of a figure who led the resistance. There are students who are good and quite good at giving responses to questions given by the teacher. Students are asked by the teacher to explain the findings about any area in the Village that were resisting Dutch colonialism, after which the teacher explains thoroughly the material taught that referring to the summary in the worksheet and textbooks owned by students (Ayundari, 2018: 40; O'Sullivan, 2019) [44, 45].

When the learning process takes place, the teacher uses problem based learning learning model, in addition to using the lecture method. The teacher gives students the opportunity to have an opinion related to the form of Lampung people's resistance to Dutch colonialism. The students are also quite active in following the learning conducted by the teacher, although not all students can answer the questions given, but the questions can provoke students to express their opinions, students also note when the teacher explains the learning material.

When learning in class is taking place, there are several things that researchers observe from the learning process carried out by the teacher, in addition to the learning methods that have been described above. First, related to time management that is adjusted to the schedule, namely 2 hours of study or 90 minutes. The use of time in each class provides the same portion, which is 10 minutes for opening lessons, 75 minutes for the core of learning and 5 minutes for closing. Second, the use of media in learning conducted by history teachers is more frequent in lectures, questions and answers and writing summaries on the board. Third, the way teachers motivate students by linking learning material with the mandate to be conveyed by the teacher, the teacher also motivates students that the values of the Piil Pesenggiri embraced by the people of Lampung play an important role in conducting resistance to Dutch colonialism.

According to the history teacher, the values of the Piil Pesenggiri are very important to be applied in the learning process of local history. The results of a research interview with Teacher Nana, she stated: "Especially students are easily influenced by things that are not good now. Related to the value of Piil Pesenggiri, the teacher holds the view that Piil Pesenggiri values that contain character education in history learning can be done through learning 
materials related to Piil Pesenggiri and implemented through learning methods. For example, in Class XI material, there is the opposition of Radin Inten II to Dutch colonialism. This material contains the values of Piil Pesenggiri". Piil Pesenggiri as the philosophy of life of the people of Lampung has the meaning of maintaining self-esteem and being firm against colonialism carried out by the Dutch. This is reflected in the attitude of the people of Lampung when led by Radin Intan II, who looked backwards in taking the fight against the Dutch occupation which would control Lampung. While the deeds and actions are on the right path, it must be done without surrender.

Piil Pesenggiri consists of: Bejuluk Beadek (Awarding), Nemui Nyimah (Friendly), Nengah Nyappur (Communication Ability), and Sakai Sambayan (Mutual Cooperation), each of these values include: i) Bejuluk Beadek, means liking a good name and honorable title. This means that with a good name and title attached to it as a leader, Radin Intan II will be responsible for defending Lampung as his birthplace so that it is not colonized and controlled by the Dutch. Although at the expense of risking their body and soul in the freedom of his people on the Dutch colonization; ii) Nemui Nyimah, implies hospitality, likes to receive and give in an atmosphere of joy and sorrow. Radin Intan II in a state of joy and sorrow always struggling in freeing Lampung from Dutch colonialism; iii) Nengah Nyappur, implies sociable and likes to communicate. Discussing in resolving a problem, Radin Intan II did not struggle alone, but was assisted by his advisers and fellow workers, who always receive advice and input from their surroundings; and iv) Sakai Sambayan, implies helpfulness and mutual cooperation in social life. Without the help of the people who gave Radin Intan II confidence in leading, it would be impossible for the struggle to last. When closing the lesson, the subject teacher with students concludes together the material that has been taught, then the teacher tells what material will be delivered at the next meeting, then closes with greetings.
The implementation of Piil Pesenggiri's values in learning history in schools is inseparable from the strategies used by the teacher itself (Bohlin, 2005; Tirri, 2009) [46], [47]. The strategy used by the teacher, that the teacher always provides reinforcement, motivation that is reminiscent of important events in the past. In addition, the history teacher gave a real example of the value of Piil Pesenggiri in the school environment, by linking the material of the people resistance in Lampung to the subject matter of the strategy and forms of resistance of the Indonesian people against Dutch colonialism.

Basically, in the history of Indonesia it has been recorded that every region throughout Indonesia carried out resistance to the Dutch occupation, only the portion of their studies in this context was quite small. Therefore, it is better if the events regarding resistance in the area are studied in local history and conveyed through history learning as an effort to bring history lessons closer to the student environment (Lickona \& Davidson, 2005) [48]. Through the 2013 curriculum, teachers can improvise learning including learning history, so that teachers' efforts to instill the values of Piil Pesenggiri values in local history can be achieved through the implementation of historical learning.

Based on the results of research conducted by researchers, shows that the implementation of the Piil Pesenggiri values in the Lampung people's resistance against the Dutch colonialism in the process of learning Indonesian history in class XI IPS students at State Senior High School 2 Kalianda has been well implemented. Based on the results of a research interview with 4 students of class XI: "It can be seen from some of the students who have been interviewed that they can cite real examples of the application of the Piil Pesenggiri values that they have done in their daily life at school and at home, including: being responsible, loving the motherland, the spirit of nationality, leadership, compassion, honesty, empathy, respect, courtesy, democracy, communicative, friendship, 
tolerance, environmental concern, social concern, and responsibility".

\subsubsection{Assessment Statge}

Based on the results of the research obtained regarding the assessment of the implementation of the values of Piil Pesenggiri local wisdom as character education in learning Indonesian history in class XI students at State Senior High School 2 Kalianda can be described below. The results obtained from the history teacher showed that the assessment of historical learning did not appear to be an assessment of the values of the Piil Pesenggiri. The lesson plan or RPP only includes assessment techniques: i) written test; ii) assignment; and iii) observation. As for the instrument form, they are: i) essay; ii) homework; and iii) observation sheet in the form: percentage observation sheet, and discussion observation sheet. Likewise, in the closing of learning activities there is no special assessment for the value of Piil Pesenggiri. It's just listed the teacher carrying out the test assessment and giving assignments to students. One of the written tests "Why during the resistance against Dutch colonialism, Radin Inten II collaborated with several other warrior figures?". This test is an indicator that students can analyze the forms of resistance of the Lampung people against Dutch colonialism. This problem contains Piil Pesenggiri values, such as: Nengah Nyappur (communication skills) and sakai sambaian (mutual cooperation/cooperation). The teacher also gives home assignment to students to practice any values that reflect the form of resistance of the people of Lampung against the Netherlands in their lives. Piil Pesenggiri values such as: Bejuluk Beadek (responsible), Nemui Nyimah (affection with others), Nengah Nyappur (making friends) and Sakai Sambayan (cooperating with each other/helping each other). The results of a research interview with Teacher Nana \& Teacher Yeni, So far I have only done the assessment by giving tests, assignments, observations of student behavior. "I have not yet fully understood how to provide an assessment of the values of Piil Pesenggiri as character education that has been embedded in the learning process activities in the classroom".

\subsection{The Barriers to the Implementation of Piil Pesenggiri Local Wisdom Values as Character Education in Learning Indonesian History at State Senior High School 2 Kalianda}

Obstacles in the implementation of Piil Pesenggiri local wisdom values as character education in learning Indonesian history, namely: first is the lack of reading book sources in learning Indonesian History. The completeness of facilities and infrastructure in the learning process does not determine the guarantee that learning activities will be good, but this is where it appears to manage the facilities and infrastructure for the implementation of learning activities to run effectively. Management of facilities and infrastructure in education units must be carried out. According to Mudjiono (2006: 249) [49], learning facilities include learning books, reading books, school laboratory tools and facilities, and various other teaching media. Learning infrastructure includes school buildings, study rooms, sports fields, worship rooms, art rooms, sports equipment and so on. Complete learning facilities and infrastructure are good conditions so as to create a good learning process. So far, the reading resources owned by the teacher in the process of learning Indonesian history are only textbooks and the Indonesian History Worksheet, not the availability of local history material. To overcome the lack of availability of reading sources, the History teacher created a 19th century Lampung community history learning module based on Problem Based Learning as a support to facilitate students in understanding local history subject matter containing values of Piil Sesenggiri given by the teacher. Teachers are also required to be creative in utilizing other reading sources such as documentary films, newspapers, and even the internet for effective learning processes. Suyanti (2016: 92) [50] explains that in the process of teaching, teachers face difficulties in finding sources or references 
for reading, finally teachers make solutions to overcome problems by finding other supporting sources or other references so that learning will be more meaningful.

The second obstacle is the negative influence of the current globalization. The 21 st century, marked by the current of globalization and supported by information, communication and transparency technology, is a challenge that has changed aspects of people's life so quickly. The impact of the current globalization has an influence on students' attitudes, behavior and morals (Thomberg, 2008: 52) [51], some students cannot filter out what is good and what is not good. Efforts are made in overcoming the negative impacts of the current globalization, namely by increasing supervision of the role of the school committee in the state senior high school 2 Kalianda in increasing the intensity of the relationship between the student guardians and homeroom teachers.

The role of the school committee must be enhanced by holding a meeting once a month to discuss and evaluate the implementation of learning in schools. Mulyasa (2002) [52] states that collaboration between school committees is very effective in fostering and shaping student behavior to fit the values that have been instilled, taught, and exemplified at school. Therefore the implementation of Piil Pesenggiri local wisdom values as character education must have the support from the collaboration between the school committee, homeroom teacher and student guardian so that it runs well.

\section{Conclusion}

Based on the results of the study it can be concluded that the implementation of Piil Pesenggiri local wisdom values as character education in learning Indonesian history in class XI students at State Senior High School 2 Kalianda has been well implemented. At the planning stage the teacher prepares a syllabus and lesson plan (RPP) by incorporating local historical material on the resistance of the people of Lampung against Dutch colonialism into Indonesian historical material contained in
KD 3.2 analyzes the strategy of the Indonesian people against European colonialism (Portuguese, Spanish, Dutch, English) until the 20th century. In the stages of the implementation of learning, teacher uses varied learning model problem based learning, in addition to other methods such as question and answer, lecture, and discussion so that students are able to understand the material and are more enthusiastic in the learning process. The evaluation phase consists of assessment techniques in the form of: written tests, assignments, and observations. As for the instrument form, they are essay, homework, and an observation sheet in the form of presentation observation sheet, as well as discussion observation sheet. Constraints encountered when implementing the values of Piil Pesenggiri local wisdom as character education in learning Indonesian history include: First, the lack of supporting reading resources in the learning process, how to overcome them the teacher makes modules to support resources in learning. Second, the influence of the negative impact of the globalization era, to overcome it is done by increasing supervision of the role of the school committee and increasing the intensity of the relationship between the parents/guardians of students with the homeroom teacher.

\section{References}

[1] S.H. Billig, D. Jesse, Grimley, Using service learning to promote character education in a large Urban District, RMC Research, Denver, Journal of Research in Character Education, 6 (2008) 21-34.

[2] S.W. Twemlow, P. Fonagy, F. Sacco, M.L. Gies, R. Evans, R. Ewbank, Creating a Peaceful School learning environment: A controlled study of an elementary school intervention to reduce violence, American Journal of Psychiatry, 158 (2001) 808-810.

[3] R. Weissbourd, Moral Teachers, Moral Students, Educational Leadership 60 (2003) 6-11.

[4] B.E. Johnson, Contextual teaching and learning, (What isits and Why its here to stay), Coewinpress, California, 2002. 
[5] J.D. Simpson, John Dewey and The Art of Teaching, Sage, California, 2005.

[6] J.S. Benninga, The Relationship of Character Education Implementation and Academic Achievement in Elementary School, Journal of Research in Character Education 1 (2003) 19-32.

[7] W. Damon, Bringing in a New era in Character Education, CA Hoover Institution Press, Stanford, 2002.

[8] W. Althof, M.W. Berkowitz, Moral Education and Character Education: Their Relationship and Roles in Citizenship Education, Journal of Moral Education 35 (2006) 495-518.

[9] Aman, Model Evaluasi Pembelajaran Sejarah, Ombak, Yogyakarta, 2011.

[10] S. Wineburg, Historical Thinking and Other Unnatural Acts: Charting the Future of Teaching the Past, Temple University Press, Philadelphia, 2001.

[11] S.K. Kochar, Pembelajaran Sejarah, PT Grasindo, Jakarta, 2008.

[12] J. Setiawan, R.S. Hadi, Nilai Pendidikan Karakter dalam materi sejarah Kebangkitan Nasional Indonesia, Sejarah dan Budaya 12 (2018) 39-49.

[13] D. Amaliah, Sariyatun, Musaddad, Value of Piil Pesenggiri: Morality, Religiosity, Solidarity and Tolerance, International Journal of Multicultural and Multireligioes Understanding 5 (2018) 179-184.

[14] R. Mulyana, Mengartikulasikan Pendidikan Nilai, Penerbit Alfabeta, Bandung, 2004.

[15] M.R. Sinaga, Revitalisasi Tradisi: Strategi Mengubah Stigma Kajian Piil Pesenggiri dalam Budaya Lampung, Jurnal Masyarakat Indonesia, 40 (2014) 109-126.

[16] F.X. Rahyono, Kearifan Budaya dalam Kata, Wedatama Widyasastra, Jakarta, 2009.

[17] A.D.I.U. Utami, W. Sariyatun, Penguatan Pendidikan Karakter Melalui Pembelajaran Sejarah Berbasis kitab Kuntara Raja Inti, Jurnal Pendidikan Sejarah Indonesia 1 (2018) 63-73.

[18] S. Priyadi, Sejarah Lokal: Konsep, Metode, dan Tantangannya, Penerbit Ombak, Yogyakarta, 2012.

[19] M.F. Tery, S. Sunardi, A.A. Musadad, Vizualitation of Portuguese Relics in Flores of Local Historical Learning, International Journal of Multicultural and Multireligious Understanding, 5 (2018) 389-391.

[20] E. Fitzsimons, Character education: A role for literature in cultivating character strengths in adolescence, Master of Applied Positive Psychology 8 (2015) 135-150.

[21] A.N. Hasudungan, Sariyatun and Sutiyah, Mainstreaming Peace Education Based on Local Wisdom Pela Gandong Post Reconciliation of Ambon Conflict in School, International Journal of
Education and Social Science Research 2 (2019) 228-238.

[22] M. Romanowski, Through the Eyes of Teachers: High School Teachers' Experiences With Character Education, American Secondary Education 34 (2015) 6-23.

[23] R. Yunus, Nilai-nilai Kearifan Lokal (Local Genius) sebagai Penguat Karakter Bangsa Studi Empiris tentang Huyula, Deepublish, Yogyakarta, 2014.

[24] F. Ariyani, Konsepsi Piil Pesenggiri Menurut Masyarakat Adat Lampung Waykanan di Kabupaten Waykanan, Aura, Bandar Lampung, 2014.

[25] S. Ali, Nilai-nilai Piil Pesenggiri Syaer Masyarakat Megou Pak Tulang Bawang dan Relevansinya dengan Pendidikan Karakter, Tesis: FKIP Unila, 2018.

[26] J. Creswell, Penelitian Kualitatif dan Desain Riset Memilih di Antara Lima Pendekatan (Edisi ke-3), Pustaka Pelajar, Yogyakarta, 2018.

[27] Sugiyono, Metode Penelitian Kuantitatif, Kualitatif dan R\&D, Afabeta, Bandung, 2015.

[28] M.B. Miles, A. Dan Huberman, Analisis Data Kualitatif Buku Sumber tentang Metode-Metode Baru, Terjemahan Tjetjep Rohendi Rohisi, Universitas Indonesia, Jakarta, 2007.

[29] M.Q. Patton, Metode Evaluasi Kualitatif, Pustaka Pelajar, Yogyakarta, 2009.

[30] Sukmadinata, Metode Penelitian Pendidikan, Remaja Rosda Karya, Bandung, 2005.

[31] A. Agboola, K.C. Tsai, Bring character education into classroom. European Journal of Educational Research 1 (2012) 163-170. https://doi.org/10.12973/eu-jer.1.2.163.

[32] U. Siswati, Muntholid, Implementasi Pendidikan Karakter dalam Membentuk Sikap dan Perilaku Sosial Peserta Didik Melalui Pembelajaran Sejarah di SMA PGRI 1 Pati Tahun Pelajaran 2017/2018, Jurnal Indonesian Juornal of History Education 6 (2018) 1-13.

[33] Sutarmi, Raharjo, Pramono, Implementasi Pelaksanaan Pendidikan Karakter sebagai landasan wawasan kebangsaan di SMA Negeri 1 Kendal, Kabupaten Kendal, Jurnal of Educational Social Studies 5 (2016) 136-144.

[34] J. Creswell, Riset Pendidikan: Perencanaan, Pelaksanaan, dan Evaluasi Riset Kualitatif dan Kuantitatif Edisi Kelima, terjemahan Helly Prajitno Soetjipto dan Sri Mulyantini Soetjipto, Pustaka Pelajar, Yogyakarta, 2015.

[35] A. Majid, Perencanaan Pembelajaran Sejarah: Pengembangan Standar Kompetensi Guru, PT Remaja Rosdakarya, Bandung, 2013.

[36] S.U. Lestari, U. Saraswati, A. Muntholib, Penanaman Nilai-nilai Nasionalisme dalam 
Pembelajaran Sejarah Lokal Perjuangan Rakyat Sukorejo Kelas XI di SMA Negeri 1 Sukorejo. Indonesian Journal of History Education 6 (2018) 205-215.

[37] Warsono, Hariyanto, Pembelajaran Aktif, PT Remaja Rosdakarya, Bandung, 2017.

[38] O. Hamalik, Perencanaan Pengajaran Berdasarkan Pendekatan Sistem, Bumi Aksara, Jakarta, 2011.

[39] I.N.A. Najib, Penanaman Sikap Nasionalisme Melalui Mata Pelajaran Muatan Lokal Wawasan Kebangsaan Pada Siswa Kelas VIII di SMP N 1 Nglegok Kabupaten Blitar, Jurnal Pendidikan Kewarganegaraan 2 (2013) 1-21.

[40] Chairiyah, Implementasi Pendidikan karakter melalui nilai-nilai kearifan lokal di SD Taman Siswa Jetis Yogyakarta, Jurnal Pendidikan Ke-SD-an, 4 (2017) 208-215.

[41] A.G. Harrison, How do teachers and textbook writers model scientific ideas for students?, Research in Science Education 31 (2001) 401-435.

[42] S. Kagan, Teaching for character and community, Educational Leadership 59 (2001) 50-55.

[43] R. Wiriaatmaja, Nasionalitas, Etnisitas, dan Integrasi Bangsa dalam Pembelajaran Sejarah, Universitas Pendidikan Indonesia, Bandung, 2002.
[44] L. Ayundari, Relevansi nilai-nilai perjuangan KH, Masjkur dalam pembelajaran sejarah berbasis pendidikan karakter bagi siswa MA di Malang, Jurnal sejarah Indonesia 1 (2018) 40-52.

[45] S. O'Sullivan, Books to live by: Using children's literature for character education, The Reading Teacher 57 (2019) 640-645.

[46] K.E. Bohlin, Teaching character education through literature, Routledge falmer, London \& New York, 2005.

[47] K. Tirri, Character education and giftedness, High abilit studies 20 (2009) 117-119.

[48] T. Lickona, M. Davidson, Smart and good high schools: Integrating excellence and ethics for success in school, Work and beyond, Character education partnership, Washington DC, 2005.

[49] D. Mudjiono, Belajar dan pembelajaran, Rineka cipta, Jakarta, 2006.

[50] Suyanti, Implementasi nilai-nilai perjuangan diponegoro dalam pembelajaran IPS di SD diponegoro, Premiere educandum 6 (2016) 84-94.

[51] R. Thomberg, Values education as the daily fostering of school rules, Research in education, 80 (2008) 52-62.

[52] Mulyasa, Kurikulum berbasis kompetensi, rosdakarya, Bandung, 2002. 